\title{
ZMĚNY VE STYLU EKONOMICKÉHO MYŠLENÍ - ŠANCE PRO TRVALE UDRŽITELNÝ ROZVOJ SPOLEČNOSTI NEBO PRO ZELENÝ EKONOMICKÝ RŮST?
}

\author{
EVA CUDLÍNOVÁ
}

\section{1. Úvod}

V 70. letech dvacátého století se objevuje nový způsob ekonomického uvažování, které se začíná zabývat otázkou životního prostředí, jsou to dnes známé ekonomické směry environmentální ekonomie, ekonomie přírodních zdrojů a ekologické ekonomie. Na začátku 21. století se objevuje další směr - tzv. "green economy“ - neboli zelená ekonomika. Vznik nových ekonomických směrů je velice často reakcí na změny ve vývoji prrírodních podmínek a přírodních zdrojů, ale také na změny ve společnosti a v ekonomické situaci.

Změna ekonomického př́stupu v 70. letech 20. století byla především reakcí na energetickou krizi, spojenou se skokovým nárůstem cen ropy a na změny v oblasti životního prostředí. Energetická krize, jako velice citlivé téma $\mathrm{z}$ hlediska paradigmatu ekonomického růstu, vedla $\mathrm{k}$ zamyšlení nad rolí přírodních zdrojů jako surovin a významných vstupů do ekonomického procesu výroby a spotřeby. V roce 1969 schválil Kongres USA National Environmental Policy Act (NEPA) a začaly být přijímány zákony na ochranu vod, vzduchu, divoké zvěře apod. V roce 1970 byla v USA založena první vládní agentura Environmental Protection Agency (EPA) na ochranu životního prostředí.

V roce 1972 se ve Stockholmu konala také první Světová konference OSN o životním prostředí lidstva. Byly na ní vymezeny tři hlavní problémové oblasti, o kterých se jedná dodnes. Sedmdesátá léta dvacátého století lze považovat za dobu vzniku termínu životní prostředí a nutnosti jeho ochrany.

Vznik zelené ekonomie na počátku 21. století je spojen s globální ekonomickou finanční krizí a zvyšující se důležitostí fenoménu globálních klimatických změn. Obdobně jako v 70. létech dvacátého století jde o spojení změn přírodního a ekonomického fenoménu. Globální finanční krize se začala projevovat již v polovině roku 2007, kdy se začala šírit nejistota $\mathrm{z}$ amerického nemovitostního trhu. V roce 2008 se globální finanční systém začal potýkat s nedostatečnou likviditou a rozsáhlou insolventností finančních institucí.

Problematika globálních klimatických změn se zpočátku objevovala jako hrozba globálního oteplování naší planety. První reakcí společnosti na globální úrovni bylo přijetí Rámcové úmluvy o změně klimatu na Summitu země v Riu de Janeiru v roce 1992. Rámcová úmluva odstartovala dlouhý řetěz mezinárodních jednání, navazujících smluv a protokolů, z nichž nejznámějším je Kjótský protokol přijatý v roce 1997, ratifikovaný v roce 2006163 státy světa. Následovaly další konference o změně klimatu, např̀ v Kodani na podzim roku 2009 a v Cancúnu v lednu 2011. 
V roce 2009 vydává Program OSN pro životní prostředí (UNEP) dokument Global Green New Deal, v němž se vyskytuje i pojem zelená ekonomika. Tento dokument je často spojován s vizí amerického prezidenta Franklina Roosevelta během Velké deprese 1930. Jeho New Deal znamenal posílení role vlády v řešení krize. Realizace myšlenek Global Green New Deal by měla přispět k oživení globální ekonomiky a zároveň řešit klimatické změny i otázku chudoby třetích zemí. Zelená ekonomika tak nabízí řešení všech velkých problémů současné doby: nastartování ekonomického růstu, řešení klimatických změn i sociální nerovnosti mezi státy.

Článek se zabývá srovnáním environmentálně zaměřených ekonomických směrů, pokud jde o jejich vztah ke koncepci trvale udržitelného rozvoje. Snaží se odpovědět na otázku, do jaké míry slouží ekonomické teorie podpoře a praktickému naplnění konceptu trvale udržitelného rozvoje společnosti.

\section{Charakteristika trvale udržitelného rozvoje}

V roce 1983 byla ustanovena Světová komise pro životní prostředí a rozvoj, vedená norskou ministerskou předsedkyní Gro Harlem Brundtlandovou. Úkolem této komise bylo prověřit vztah mezi hospodářským rozvojem a životním prostředím. Šlo o revizi výzkumné studie Ř́mského klubu a jejího závěru o nutnosti nulového ekonomického růstu [Meadows et al. 1972]. Mezinárodní komise odborníků pracovala tři roky a výsledkem její práce byla v roce 1987 publikace „Naše společná budoucnost“. V této zprávě byl poprvé použit termín „sustainable development“ (SD) neboli trvale udržitelný rozvoj a jeho známá definice, která hovoří o čerpání zdrojů současnou generací, tak, aby nedošlo ke zkrácení možností uspokojování potřeb generací budoucích [World Comission on Environment and Development 1987]. Tato definice se stala všeobecně známou a citovanou jak v odborné literatuře [Backerman 1994; Daly 1996; Neuymayer 1999], tak v politických a strategických dokumentech na národní i světové úrovni [Strategie trvale udržitelného rozvoje EU 2001; Sweden's national strategy for sustainable development 2001; Norway's Strategy for Sustainable Development 2008].

Existuje celá řada interpretací široce definovaného pojmu trvalé udržitelnosti, včetně diskusí o termínu samotném. Nejčastěji se uvádí, že trvale udržitelný rozvoj má tři dimenze - ekologickou, ekonomickou a sociální. Ekonomický přístup klade důraz na efektivnost, růst, stabilitu a zaměstnanost. Sociální přístup je zaměřen na chudobu, kulturní dědictví, mezigenerační rovnost, účast občanů na rozhodovacích procesech a zaměstnanost. Environmentální přístup si všímá především biodiverzity, prrírodních zdrojů a znečištění [Meadows 1998; Backerman 1994]. Jednotlivé interpretace a přístupy k trvale udržitelnému rozvoji se liší také podle toho, zda zdůrazňují environmentální, sociální nebo ekonomické hledisko.

Podstata trvale udržitelného rozvoje je metodologicky natolik obsáhlá, že existují různé přístupy k definování trvalé udržitelnosti i pokud jde o míru radikálnosti, zachování př́rodních zdrojů neboli přírodního kapitálu. Dva krajní body definice představuje tzv. „slabé a silné" pojetí trvalé udržitelnosti, které se liší v názoru na zastupitelnost jednotlivých druhů kapitálu. Zatímco zastánci „slabé definice“ se přiklánějí k názoru, že pro trvale udržitelný rozvoj je postačující zachovat neměnné množství kapitálu společnosti 
(bez ohledu na to, zda jde o prrírodní, kulturní nebo člověkem vytvořený), stoupenci „silné definice " považují za nutný předpoklad udržitelnosti rozvoje zachovat množství přírodního kapitálu konstantní [Pearce et al. 1992; Neumayer 1999; Dasgupta 1994; Daly 1996].

Trvale udržitelný rozvoj představuje první politicky deklarovaný a mezinárodně přijatý způsob uvažování o ekonomickém rozvoji a nikoli ekonomickém růstu. Jde o všeobecně uznávaný milník v uvažování o dlouhodobě udržitelném zpơsobu existence lidstva na planetě Zemi. Byly mu věnovány i dvě velké světové konference, zaměřené na domluvu o praktické realizaci hlavních zásad trvale udržitelného rozvoje. První byla v Rio de Janeiro v roce 1992 a druhá o deset let později v Johannesburgu 2002, označovaná jako Rio+10. Johannesburg nebyl zelený Summit o planetě a životním prostředí jako v př́padě Ria, ale jednání se týkalo spíše vyváženého rozvoje společnosti, kde životní prostředí je jen důležitou podmínkou pro její rozvoj. V tomto roce se konal třetí Summit, který je označován jako Rio+20 [Rio+20: Toward a New Green Economy - or a Green-Washed Old Economy? 2011].

Ačkoli uplynulo téměř dvacet let od prvního světového Summitu, který byl věnován trvale udržitelnému rozvoji, zůstává stále nezodpovězenou otázkou, jakou cestou lze myšlenky trvale udržitelného rozvoje převést do ekonomické praxe a chování společnosti.

\section{Nové ekonomické směry zohledňující životní prostředí}

Ekonomové, kteří se začali energetickou krizí a krizí životního prostředí v 70. a 80. letech 20. století zabývat, se zpočátku nedělili na žádné směry. Reagovali na popsanou situaci velice obdobně - kladli si především otázku limitů ekonomického růstu a všímali si energetických a biofyzikálních cyklů a jejich spojení s fungováním ekonomiky společnosti. Zcela zásadní otázkou byla otázka energie.

Důležitým trendem v letech 1970-1980, který umožnil vznik nového ekonomického myšlení, byl vzrůstající zájem o transdisciplinaritu (hranice mezi disciplínami jsou jen akademický konstrukt, jednotlivé obory se nedrží svých př́ístupů, nástrojů zkoumání a vymýšlejí si nové, společné př́istupy k analýze problému). Vzhledem k transdisciplinaritě byl tak simultánně zkoumán vztah ekonomického systému a jeho závislosti na energii na straně jedné a energetických toků v rámci ekosystémů na straně druhé. Zásadní byla práce fyzika Prigogina a jeho vědecké skupiny v Belgii, kteří zavedli koncept sebeorganizujícího se disipativního systému [Prigogine 1973; Prigogine, Stengers 1977]. Další práce, která ovlivnila ekologické myšlení, byl článek Hollinga z roku 1973, ve kterém obrací pozornost od studia rovnovážných systémů $\mathrm{k}$ otázce pružnosti ekologických systémů při jejich reakci na stresový faktor [Holling 1973]. Později došlo k názorovému odlišení environmentální ekonomie, ekonomie př́rodních zdrojů a ekologické ekonomie.

\section{Environmentální ekonomie}

Environmentální ekonomie se zaměřila jen na ekonomickou stránku problémů s životním prostředím a jejich nápravu. Řeší optimalizaci rozmístění a využití zdrojů v rámci ekonomiky společnosti. Zabývá se především otázkou znečištění životního prostředí a nástroji, které by mohly vést $\mathrm{k}$ jeho omezení. Ekonomie př́rodních zdrojů se zabývá 
oceňováním vzácných zdrojů a jejich zahrnutím do ekonomického rozhodování v rámci nákladově ziskové analýzy [Ropke 2004].

Environmentální ekonomie a ekonomie přírodních zdrojů patří pod neoklasickou ekonomii - jsou tedy součástí hlavního ekonomického proudu myšlení. Od hlavního proudu ekonomie se liší pouze tím, že do svých teoretických koncepcí zahrnuly životní prostředí jako selhání funkce trhu a oceňování přírodních zdrojů.

Hlavním projevem selhání funkce trhu působení tržních sil v procesu optimální alokace zdrojů jsou externality. Externality jako funkci trhu poprvé zmínil Alfred Marshall [Marshall 1890]. Externality jako rozdíl mezi společenskými a individuálními náklady popsal Pigou v roce 1920 [Pigou 1928]. Environmentální ekonomové se začínají zabývat teorií externalit v souvislosti se znečištěním životního prostředí. Externality jsou často definovány z nákladového hlediska jako rozdíly mezi společenskými náklady či výnosy ekonomické aktivity a jejími soukromými náklady či výnosy.

Ačkoli se environmentální ekonomie a ekonomie přírodních zdrojů zabývají rozměrem př́rody $z$ ekonomického úhlu pohledu, mají odlišné kořeny.

Ekonomie přírodních zdrojů má své kořeny v neoklasické růstové ekonomice a začala se vyvíjet už v 19. století. Kořeny environmentální ekonomie jsou ve „welfare economics“ (ekonomie blahobytu a prosperity) a studiu tržních selhání - „market failure“ [JEEM Special Issue 2000; Cropper, Oates 1992]. Etické kritérium klasické a neoklasické ekonomie je odvozeno od morální filosofie užitku a užitečnosti (David Hume, Jeremy Bentham, John Stuart Mill). Sociální blahobyt spočívá na průměrné míře užitku, kterého dosahují všichni členové společnosti [Pareto 1897]. Jde o teorii efektivní alokace zdrojů, jestliže není splněna efektivní alokace zdrojů a společnost se nepohybuje po Paretově optimální křivce, pak dochází k selhání funkce trhu.

V roce 1979 byla ustavena Asociace environmentálních ekonomů a ekonomů přírodních zdrojů (AERE) v USA, která vydává časopis Journal of Environmental Economics and Management (JEEM) [Ropke 2004]. K hlavním představitelům patří David W. Pearce, Kerry Turner, Tom Tienterberg, William Nordhaus. Uvádíme zde jen některá nejznámější jména $\mathrm{z}$ celé řady vědců, kteří jsou zastánci tohoto směru myšlení.

\section{Ekologická ekonomie}

Ekologická ekonomie se soustředila na biofyzikální a energetickou koncepci propojenosti společnosti a prŕrody a vytvořila nové odvětví ekonomie s novým paradigmatem trvalé udržitelnosti života na planetě Zemi. Klade důraz na etické otázky rovnosti v přístupu ke zdrojům i rozdělování př́ímů a to jak mezigeneračně, tak geograficky mezi státy. Efektivnost alokace prrírodních zdrojů nechápe pouze v rámci společnosti, ale především mezi společností a planetou Zemí. Zavádí pojem „carrying capacity of biosphere“ - únosná míry kapacity Země.

Název ekologická ekonomie byl ovlivněn složením vědecké komunity, která byla u zrodu této disciplíny. V souvislosti s řešeným problémem udržitelnosti života na naší planetě se právě ekologie a ekonomie zdály být hlavní disciplíny, které mohly daný problém vyřešit.

Za jednoho ze zakladatelů ekologické ekonomie je uznáván Kenneth Boulding se svou prací z roku 1966 The Economics of the Spaceship Earth [Boulding 1966]. Základní 
myšlenkou jeho práce je charakteristika ekonomie jako otevřeného systému, ve kterém platí zákony termodynamiky - zachování energie a zvyšující se entropie. Druhá zásadní kniha pro vznik ekologické ekonomie vyšla v roce 1971, je jí The Entropy Law and the Economic Process [Georgescu-Roegen 1971]. Třetí pak byla Steady State Economics [Daly 1991].

Idea „steady state“ byla poprvé zmíněna v roce 1848 jako „stationary state“ Johnem Stuartem Millem. Termín „stationary state“ byl použit pro populaci a kapitál, kdy míra porodnosti se rovná míre úmrtnosti a míra výroby míře spotřeby. Millův „stationary state “ale neznamená konec lidského zlepšování kvality znalostí a života, je to určitá obdoba s ideou trvale udržitelného rozvoje založenou na kvalitativním a ne kvantitativním růstu.

Paradigma ekologické ekonomie mění přístup k definici efektivnosti, optimální alokaci i měřítku, v němž se ekonomie pohybuje. Zaměřuje se především na makroekonomii. Nehledá optimální rozdělení a využití přírodních zdrojů v rámci společnosti a pro společnost, ale hledá optimální rozměr ekonomiky, vzhledem k únosné míře kapacity naší planety. Její měřítko je globální, nebot globální problémy potřebují globální řešení.

Ekologická ekonomie byla institucionalizovaná v roce 1989 vznikem Mezinárodní společnosti pro ekologickou ekonomii (ISEE ) v USA, v roce 1990 vyšlo první ćíslo vědeckého časopisu Ecological Economics. K současným hlavním představitelům ekologické ekonomie patří Herman Daly, Mick Common, Robert Costanza, Sylvie Faucheux, Carl Folke, John Gowdy, AnnMari Jansson, Joan Martinez-Alier, Charles Perrings, John Proops, Clive Spash a Peter Soderbaum.

\section{Zelená ekonomika}

Jestliže v 80. letech 20. století byla pro změnu úvah o dalším ekonomickém rozvoji zásadní zprávou Naše společná budoucnost [World Comission on Environment and Development: Our Common Future 1987] a pojem trvale udržitelného rozvoje, na počátku 21. století je to dokument „Green New Deal“ a v něm pojem zelená ekonomika neboli Green Economy [Global Green New Deal, An Update for the G20 Pittsburgh Summit 2009].

Jednotná definice zelené ekonomiky, která by byla dohodnutá členskými státy OSN, není prozatím k dispozici. Ve zprávě generálního tajemníka OSN pro první prípravné setkání United Nations Conference on Sustainable Development (UNCSD), byly určeny 4 shodné prvky zelené ekonomiky. „Jeden prvek dává odpověd’ na otázku zelené ekonomiky pomocí analýzy selhávání trhu a internalizaci externalit. Jiný má systémový pohled na ekonomickou strukturu a její vliv na relevantní aspekty udržitelného rozvoje. Třetí je zaměřen na dosažení sociálních cílů (např. pracovních míst) a zkoumá vedlejší politiky potřebné ke sladění sociálních cílů s ostatními cíly hospodářské politiky. Čtvrtá část se zaměřuje na makroekonomický rámec a strategii rozvoje s cílem identifikace dynamického propojení směrem k udržitelnému rozvoji." [Definitions of a Green Economy 2010]

Podle Organizace spojených národů pro životní prostředí je zelená ekonomika ta, která zlepšuje lidské blaho a sociální spravedlnost a přitom významně snižuje ohrožení životního prostředí [Towards a Green Economy: Pathways to Sustainable Development and Poverty Eradication - A Synthesis for Policy Makers 2011].

Definice zelené ekonomiky podle Konference OSN o obchodu a rozvoji (UNCTAD) z roku 2010 říká, že zelená ekonomika v dlouhodobém horizontu může být definována 
jako ekonomika, která vede ke zlepšení životních podmínek lidí - pohody a snížení nerovností, aniž by vystavila budoucí generace významným rizikům životního prostředí a ekologických nedostatků. Během přechodné fáze usiluje zelená ekonomika o dlouhodobý společenský př́nos pro krátkodobé aktivity zaměřené na zmírnění rizik pro životní prostředí. Tam je totiž podle UNCTAD potenciál ekonomického růstu, který bude šetrný k životnímu prostředí a bude sloužit jako silný nástroj pro rozvoj [The Green Economy: Trade and Sustainable Development Implications 2010].

Množství definic vypovídá o tom, že koncept zelené ekonomiky je velmi mladý a spiše, než jako vědecky podložená teorie, vznikal jako reakce společnosti na ekonomickou a finanční krizi z počátku 21. století. V některých definicích se tak objevuje ekonomický růst, zatímco jiné jsou svým vymezením téměř identické s definicí trvale udržitelného rozvoje.

\section{Charakteristika nových ekonomických směrů s ohledem na trvale udržitelný rozvoj}

\section{Environmentální ekonomie a ekonomie př́rodních zdrojů z pohledu trvalé udržitelnosti}

Environmentální ekonomie a ekonomie př́rodních zdrojů jsou zaměřeny na optimální alokaci zdrojů v rámci ekonomiky a jejich orientace je na ekonomický růst, nikoli na jeho zastavení nebo změny na rozvoj.

Nezabývají se otázkou rozměru ekonomiky vůči naší planetě, není pro ně nutné zabývat se otázkou limitů a ukončení růstu. Podle environmentální ekonomie není třeba měnit hodnoty společnosti, $\mathrm{k}$ vyřešení problémů s životním prostředím povede technický a technologický pokrok, který vyřeší nedostatek zdrojů i znečištění životního prostředí. Podle tohoto ekonomického směru myšlení existuje absolutní substituovatelnost zdrojů a jedinou překážkou růstu je technický pokrok [Tietenberg 1988; Noorgard 1984].

Znečištění je z ekonomického úhlu pohledu nákladem, vznik znečǐ̌sění je tak jen opomíjení důležitých nákladů - externích nákladů [Randall 1987]. Podle environmentálních ekonomů je určitá míra znečištění nutná, neb souvisí s výrobou a životem společnosti. Optimální znečištění tak podle ekonomického př́stupu není nulové znečištění, jak by požadovali ekologové, ale určitá míra znečištění, kterou je společnost ochotna tolerovat.

\section{Ekologická ekonomie a trvale udržitelný rozvoj}

Ekologická ekonomie vychází z filosofie trvale udržitelného rozvoje [World Comission on Environment and Development 1987], což charakterizuje i motto ekologické ekonomie: Lidská společnost a ekonomie jsou součástí systému biosféry, proto je třeba ekonomické procesy chápat zároveň i jako př́rodní procesy - jako fyzikální a chemické procesy transformace. Ke studiu ekonomie by se mělo přistupovat také jako k př́rodnímu objektu, s tím vědomím, že v ekonomii je tento prírodovědný př́stup pouze doplňující, nikoli jediný [Ropke 2004].

Ekologičtí ekonomové rozšiřují pojem kapitálu, původně užívaného jen pro oblast výroby, také na produkci přírody - zavádějí pojem přírodní kapitál, kam patří přírodní 
zdroje a ekosystémové služby. Koncept ekosystémových služeb vychází z principu, že na ekosystémové funkce lze také nahlížet jako na služby (produkce komodit, energie, čištění vody, protipovodňová ochrana), více na www.ecosystemservices.org.uk. Ekologická ekonomie podporuje definice tzv. silné udržitelnosti, kdy pro zachování trvale udržitelného života na naší planetě nestačí pouze udržovat celkovou velikost kapitálu pro budoucí generace, ale je třeba, aby se neztenčovalo množství kapitálu př́rodního [Neumayer 1999]. Tento požadavek logicky vyplývá ze zásady ekologické ekonomie, podle níž neexistuje absolutní substituovatelnost zdrojů, ale pouze jejich komplementarita, a to především mezi př́rodním a člověkem vytvořeným kapitálem.

Nové ekonomické paradigma ekologické ekonomie je normativní. Nepopisuje svět jaký je, ale jaký by měl být. Reaguje na změnu, která nastala, kdy limitem ekonomického růstu není technický pokrok a člověkem vytvořený kapitál, ale limitem jsou přírodní zdroje a ekosystémové služby. Ekologická ekonomie přichází se zásadně novým hodnotovým paradigmatem, podle něhož primární hodnoty představuje příroda a její ekosystémy a všechny ostatní hodnoty v ekonomickém systému jsou hodnotami sekundárními. Ekonomický růst není cílem sám o sobě dokonce ani optimální alokace zdrojů a efektivnost výroby není cílem, který vše vyjadřuje a jemuž je třeba se podřídit. Je to jen podmínka lidského života, jedna z podmínek, ne jediná. Je třeba přijmout určitá etická kriteria ekonomické aktivity, která určí hranice, v nichž je dán prostor trhu a jeho alokační funkci.

Ekologická ekonomie má třri základní cíle:

1) Přijatelný rozměr „sustainable scale“, jehož kritérium je udržitelnost života lidí na této planetě.

2) Spravedlivé rozdělování př́ijmů v rámci společnosti i mezi státy, kritérium je spravedlnost.

3) Efektivní alokaci zdrojů - důležité je politické vymezení prostoru, kde bude trh působit.

První dva cíle nejsou obvykle předmětem zkoumání tržní ekonomiky, jsou to cíle více ze sféry biofyzikální a kulturní. Musí být proto sociálně a politicky determinovány a jako politické cíle prosazovány více méně simultánně.

Třetí cíl se týká trhu a prostoru jeho působení. Trh bude, v rámci daných politicko-sociálních limitů, alokačně určovat efektivní ceny. Důležité jsou politické limity - vymezení prostoru, kolik se kde bude čerpat a využívat přírodních zdrojů (obnovitelných i neobnovitelných) a kdo bude určovat pravidla - otázka distribuce pravomocí. Pak může nastoupit řešení problému efektivní alokace zdrojů v rámci určených limitů čerpání a pravidel distribuce [Daly, Farley 2004].

\section{Zelená ekonomika a trvale udržitelný rozvoj}

Dokument „Global Green New Deal“, který se do určité míry stává ústředním pojmem 21. století má určité shodné rysy s paradigmatem trvale udržitelného rozvoje. Rozdíl je v tom, že jde o posun od paradigmatu na praktickou realizaci trvale udržitelného rozvoje ve všech jeho dimenzích: ekonomické, ekologické i sociální. Global Green New Deal je 
vlastně jakýmsi „akčním programem“ zelené ekonomiky, je to rozpracovaná strategie, jak zeleného rozvoje dosáhnout. Hlavní cíl Green New Dealu se dá zjednodušeně vyjádřit jako úsporné hospodaření s přírodními zdroji a podpora alternativních technologií k výrobě energie. Musí jít o takový rozvoj, který povede k levné energii z alternativních, především obnovitelných zdrojů. Zelená ekonomika v kontextu trvale udržitelného rozvoje je jedním z hlavních témat konference Rio+20 v roce 2012.

Strategie zelené ekonomiky znamená minimalizovat spotřebu energie a zdrojů a minimalizovat ekonomické dopady na životní prostředí prostřednictvím tzv. zelených investic do nových technologií [Pearce et al. 1989]. Zelené investice budou zároveň impulsem ekonomického růstu a zaměstnanosti. K praktickému naplnění uvedených cílů ve zprávě UNEP z roku 2011 doporučuje věnovat dvě procenta světového HDP do investic v deseti klíčových odvětvích. Investice dvou procent globálního HDP do deseti klíčových odvětví mohou začít přechod k nízkouhlíkové, energeticky účinnější, zelené ekonomii. K deseti odvětvím, kam vložit peníze pro změnu ekonomiky patř́i: ekologizace zemědělství, rybolovu a lesního hospodářství, ekologizace budov prostřednictvím zlepšení energetické účinnosti, využití ekologických energií alternativních a obnovitelných zdrojů, ekologizace průmyslu, dopravy a cestovního ruchu, likvidace a recyklace odpadi̊, ekologizace odvětví vodního hospodářství, včetně řešení kanalizace [How Two Per Cent of Global GDP Can Trigger Greener, Smarter Growth While Fighting Poverty 2011].

Ačkoli se koncept zelené ekonomiky odvolává na teoretický základ ekologické ekonomie a myšlenky trvale udržitelného rozvoje, není jasné, zda nejde především o podporu ekonomického „zeleného růstu“ a ne trvale udržitelného rozvoje.

\section{Diskuse - limity růstu a externality}

Neoklasičtí ale i environmentální ekonomové někdy argumentují tím, že určení rozměru či limitů ekonomiky není potřeba, nebot’ máme-li perfektní informace a můžeme-li internalizovat externí náklady a zisky do cen, pak trh automaticky zastaví růst na optimálním rozměru ekonomiky.

První slabinou, podle ekologických ekonomů, je neexistence perfektních informací. I když informovanost přijmeme jako předpoklad, musíme vyžadovat, aby ceny odrážely nejen náklady a zisky různých rozměrů, velikosti ekonomiky, ale též náklady a zisky různého rozdělování [Daly, Farley 2004]. Ekologická ekonomie nepopírá význam externalit, ale jejich příčiny vzniku i způsoby, jak se s nimi vyrovnat vidí jinde než environmentální ekonomie. I kdyby všechny externí náklady byly internalizovány a vložily se do cen výrobků a nákladů výroby, sám trh by nemohl řídit ekonomiku trvale udržitelně vzhledem k míře únosné kapacity naší planety. Je třeba si uvědomovat existenci limitů růstu, nebot pro některé zboží a služby je nevhodné použít trh jako řešení nezávisle na tom, zda jsme schopni internalizovat externality nebo ne. Některé vedlejší (externí) náklady růstové strategie přicházejí jako překvapení (např. globální změna klimatu). I když už jsou externí náklady viditelné, ekonomie reaguje se zpožděním a ještě internalizace externích nákladů je jen částečná vzhledem k neurčitosti, nedokonalosti našich informací a zhodnocení všech souvislostí.

Řešení navrhované ekologickými ekonomy je nejprve zajistit politicky prostor pro působení trhu a v něm pak nechat působit ceny. Distribuce na makro úrovni a limity 
rozměrů ekonomiky odrážejí sociální a společenské hodnoty spravedlnosti a trvalé udržitelnosti, které nejsou součtem osobních preferencí jednotlivců a nemohou se projevit prostřednictvím individuálních tržních akcí. Jsou-li společenské preference zajištěny na politické, vládní úrovni, ceny pak mohou internalizovat společenské hodnoty a provádějí efektivní alokaci. Zásadní rozhodnutí o ekonomickém růstu či rozvoji nelze ponechat na působení cen [Daly, Farley 2004].

Zelená ekonomika se limity růstu vůbec nezabývá. V dokumentech a doporučeních se hovoří o změně růstu na růst zelený, nikoli o jeho limitech a omezeních. Existují obavy, zda zelená ekonomika není především zelenou pro bankéře a inženýry, kteří budou financovat a navrhovat nové technologie. Zda tato nově obarvená ekonomie staré tzv. „hnědé“ ekonomie na „zelenou“, nepovede ke stejným cílům, jen jinak pojmenovaným. Obavy plynou z důrazu na technologie, trh, investice a růst. Otázky týkající se sociální rovnosti zůstávají v pozadí. Zdá se, že jde o alternativu k novému typu ekonomického růstu, zeleného, šetrného k životnímu prostředí, ale přeci jen růstu, který se měří růstem HDP [Rio+20: Toward a New Green Economy - or a Green-Washed Old Economy? 2011].

Jde o soutěž v zeleném růstu, kdo dá víc na zelené investice. Orientaci na investice do zeleného růstu dotvrzuje i prohlášení evropské komisařky pro regionální politiku Danuty Hübnerové, které bylo uvedeno pod názvem Kohezní politika podporuje „zelenou ekonomiku“ ve prospěch růstu a dlouhodobého zajištění pracovních míst v Evropě.

Třicet procent $\mathrm{z}$ fondů na podporu regionálního rozvoje v Evropě na období 2007-2013 bude věnováno na podporu v tváření nových pracovních příležitostí a podporu Evropy v oblasti zelených technologií. [Cohesion Policy backs „green economy" for growth and long-term jobs in Europe 2009]

Kritika konceptu zelené ekonomiky upozorňuje na to, že zelená ekonomika se nezabývá prríčinami globálních negativních jevů, jako je chudoba a znehodnocené životní prostředí. Snaží se pouze o řešení projevů a dopadů těchto negativních jevů. Jako řešení navrhuje nové uspořádání finančního managementu ekosystémových služeb prostřednictvím zelených daní a ochranu životního prostředí pomocí uvolnění prostředků na zelené technologie.

Koncept zelené ekonomiky se odvolává na teoretický základ ekologické ekonomie a aplikaci myšlenek trvale udržitelného rozvoje. Praktická realizace je ale bližší teorii environmentální ekonomie a ekonomii přírodních zdrojů. Environmentální ekonomie a ekonomie př́rodních zdrojů jsou zaměřeny na optimální alokaci zdrojů v rámci ekonomiky, jsou orientovány na ekonomický růst, nikoli na rozvoj, jako je tomu u ekologické ekonomie. U zelené ekonomiky jde také o podporu růstu. Zelené technologie, které jsou pro tento typ růstu navrhovány, úzce souvisí s myšlenkami absolutní substituce zdrojů, kdy limitem růstu je pouze technický pokrok.

Popsané alternativní ekonomické směry reagují na nové výzvy společnosti - chudobu, ohrožené přírodní zdroje a degradaci životního prostředí ve formě ekosystémů a jejich funkcí. Tyto výzvy si však překládají povětšinou do svého jazyka: Problém funkcí ekosystémů je převeden na optimalizaci ekosystémových služeb, př́rodní zdroje do ekonomického ocenění jejich hodnoty a chudoba do snížení transakčních nákladů s jejím 
vymizením. Otázky řešení složitých a svým rozsahem globálních problémů naší doby se vrací k osvědčenému ekonomickému paradigmatu nákladově ziskové analýzy, jinými slovy hledání odpovědi na otázku peněz na péči o životní prostředí - můžeme si to dovolit? K častým ekonomickým argumentům obhajoby růstu patří, že světová ekonomika musí růst, abychom mohli nastolit sociální rovnost lidí na zemi a vyrovnat situaci třetího světa s ekonomikou bohatých států Evropy a Ameriky.

\section{Závěry}

Článek poukazuje na některá slabá místa konceptu zelené ekonomiky, pokud jde o praktickou realizaci principů trvale udržitelného rozvoje. Je třeba ještě jasněji specifikovat propojení s principem trvalé udržitelnosti, zvláště pak návrhy různých politických opatření, která jsou uváděna pod praporem „zelená ekonomika“. Je třeba také provést důkladnější analýzu, pokud jde o soulad ekologických, ekonomických a sociálních cílů, které jsou zelenou ekonomikou propagovány, a to s ohledem na specifika národních ekonomik. Zvláštní pozornost bude třeba věnovat institucionálnímu zabezpečení, pokud jde o prosazení cílů zelené ekonomiky.

Vzhledem k tomu, že „zelená ekonomika“" vznikla jako reakce na současnou ekonomickou krizi, jde především o podporu růstu a odvětví, která tento růst umožní nastartovat (zelené technologie, zelená energetika atd.) a vytvoří nová pracovní místa. Nejedná se o novou teorii, její těžiště se přesouvá do politických rozhodnutí, deklarací a praktického ekonomického života. Je proto mnohem transparentnější a zdá se i účinnější. Jde o zpomalení devastace životního prostředí, ale není to naplňování nového paradigmatu. Ačkoli se odvolává na paradigma ekologické ekonomie, má blíže k názorům environmentální ekonomie.

\section{LITERATURA}

Backerman, Wilfed. 1994. „Sustainable Development: Is it a Useful Concept?“ Environmental Values 3 (3): 191-209.

Boulding, Kenneth E. 1966. „The economics of the coming spaceship Earth.“ Pp. 3-14 in Henry Jarrett (ed.). Environmental quality in a growing economy. Baltimore: John Hopkins University Press.

Cohesion Policy backs "green economy" for grow th and long-term jobs in Europe. 2009. [online] [cit. 27. 6. 2011] Dostupný z: http://europa.eu/rapid/pressReleasesAction.do?reference=IP/09/369\&format=HTML \&aged $=0$ \&language $=\mathrm{EN} \&$ guiLanguage $=\mathrm{en}$.

Cropper, Maureen L., Wallace E. Oates. 1992. „Environmental economics: a survey.“ Journal of Economic Literature 30: 675-740.

Daly, Herman E. 1991. Steady-State Economics (2nd ed.). Washington, D.C.: Island Press.

Daly, Herman E. 1996. Beyond Growth. Boston: Bacon Press.

Daly, Herman E., Joshua Farley. 2004. Ecological Economics: Principles and Applications. Washington, D.C.: Island Press. London: Covelo.

Dasgupta, Partha. 1994. „Saving and Fertility: Ethical Issues.“ Philosophy \& Public Affairs 23 (2): 99-127.

Definitions of a Green Economy. 2010. [online] [cit. 27. 6. 2011] Dostupný z: http://www.earthsummit2012 .org/index.php/green-economy-landing/235-green-econ-definition.

Georgescu-Roegen, Nicholas. 1971. The entropy law and the economic process. Cambridge: Harvard University Press. 
Global Green New Deal, An Update for the G20 Pittsburgh Summit. 2009. [online] [cit. 27. 6. 2011] Dostupný z: http://www.unep.ch/etb/publications/Green\%20Economy/G\%2020\%20policy\%20brief\%20 FINAL.pdf.

Holling, Crawford S. 1973. „Resilience and stability of ecological systems.“ Annual Review of Ecological Systems 4: 1-24.

How Two Per Cent of Global GDP can Trigger Greener, Smarter Growth While Fighting Poverty. 2011. [online] [cit. 27. 6. 2011] Dostupný z: http://www.unep.org/greeneconomy/Portals/88/documents /ger/GER_press_en.pdf.

JEEM Special Issue. 2000. Journal of Environmental Economics and Management. 25th Anniversary Issue 39.

Marshall, Alfred. 1890. Principles of Economics. London: Macmillan \& Co.

Meadows Donella H., Dennis L. Meadows, Jørgen Randers, William W. Behrens III. 1972. The Limits to Growth. New York: Universe Books.

Meadows, Donella H. 1998. Indicators and Informations Systems for Sustainable Development, A Report to the Balaton Group. Hartland VT: The Sustainability Institute.

Neuymayer, Eric. 1999. Weak versus Strong Sustainability - Exploring the Limits of Two Opposing Paradigms. Cheltenham: Edward Eglar.

Noorgard, Richard B. 1984. „Co-evolutionary Development Potential“. Land Economics, 60 (2): 160-173.

Norway's Strategy for Sustainable Development. 2008. [online] [cit. 27. 6. 2011] Dostupný z: http://www .regjeringen.no/upload/FIN/rapporter/R-0617E.pdf.

Pareto, Vilfredo. 1897. Cours d'Economie Politique. Lausanne: Rouge.

Pearce, David W., Anil Markandya, Edward Barbier 1989. Blueprint for a Green Economy. London: Earthscan.

Pearce, David W. 1992. „Economic valuation and the natural world“. Policy Research Working Paper Series 988. The World Bank.

Pigou, Artur C. 1928. The Economics of Welfare. 3rd edition. Cambridge.

Prigogine, Ilya. 1973. „Can thermodynamics explain biological order? Round table with Ilya Prigogine and others of the Brussels school." Impact of Science on Society XXIII: 159-179.

Prigogine, Ilya, Isabelle Stengers. 1977. The new alliance. Part 1 and 2. Scientia 112: 5-8, 9-12.

Randall, Alan. 1987. Resource economics: An economic approach to natural resource and environmental policy. Second edition. New York: Wiley.

Rio+20: Toward a New Green Economy - or a Green-Washed Old Economy? 2011. [online] [cit. 27. 6. 2011] Dostupný z: http://www.cruxcatalyst.blogspot.com/2011/03/rio20-toward-new-green-economy-or -green.html.

Ropke, Inge. 2004. „The early history of modern ecological economics.“ Ecological Economics. 50 (3-4): 293-314.

Strategie trvale udržitelného rozvoje EU. 2001. [online] [cit. 27. 6. 2011] Dostupný z: http://www.czso.cz /csu/tz.nsf/i/strategie_eu_v_oblasti_trvale_udrzitelneho_rozvoje.

Sweden's national strategy for sustainable development. 2001. [online] [cit. 27. 6. 2011] Dostupný z: http:// www.regeringen.se/content/1/c4/28/86/46c330fd.pdf.

Tietenberg, Thomas H. 1988. Environmental and Natural Resource Economics. 2nd edition. Boston: Glenview. London: Scott, Foresman and comp.

The Green Economy: Trade and Sustainable Development Implications. 2010. [online] [cit. 27. 6. 2011] Dostupný z: http://www.unctad.org/Templates/WebFlyer.asp?intItemID=5634\&lang=1.

Towards a Green Economy: Pathways to Sustainable Development and Poverty Eradication - A Synthesis for Policy Makers. 2011. [online] [cit. 27. 6. 2011] Dostupný z: http://www.unep.org/greeneconomy /Portals/88/documents/ger/GER_synthesis_en.pdf.

World Comission on Environment and Development. 1987. Our Common Future. Oxford: Oxford University Press. 
New style of economic thinking appeared in the 1970s. These new economic trends which were focused on environment as a part of economic theory are known as environmental and resource economics. The emergence of new style of economic thinking was reaction to the great changes - energetic crises and degradation of nature and natural resources. Economists focused on these problems were not divided into any specific fields. They tried to solve the questions of limits of economic growth and relationship between economic and biophysical cycles. Later the former ecological oriented branch of economists divided into different branches - environmental and resource economics and ecological economics. The main topics of interest for environmental and resource economists were internalization of externalities and searching for methods of valuing natural resources. They paid attention just to social effects of environmental problems and tried to change the imperfect market functioning through internalization of environmental externalities. Ecological economics is based on biophysical and energetic conception of mutual linkages between economy and nature. The main goals of ecological economics is to find the adequate dimension of economy in relation with the planet Earth and fair distribution of resources among states and generations. At present a new economic field of thinking is appearing, it is a green economy. Its concept ought to be the same as ecological economics and the main goal is to achieve the sustainable development. This study tries to compare all these new concepts of economics in relation to the main idea of sustainable development. The main philosophy of green economy is a support of new green technologies and new green jobs seems to be closer to environmental than ecological economics. It seems to us that the main goal of a green economy is not sustainable development but a "green economic growth". 